\title{
Dois horizontes de uma mesma expectativa
}

\section{Rodrigo Turin}

Por onde começar. Afinal, todo texto tem que ter um começo. Pela memória, obviamente. Este é o teor do texto demandado: uma memória, um relato sobre uma experiência do passado. Evocar alguma cena, um ponto de referência, quem sabe uma anedota. Mas nenhuma imagem clara se forma, apenas fragmentos de lugares, de datas, de conversas. Fernando, em frente à sala do PET, dizendo alguma coisa sobre a ideia de criar uma revista. Uma reunião animada no ambiente escuro do... qual era mesmo o nome? Eu, desconfortável, pedindo dinheiro ao Eleotério em nome de uma propaganda na contracapa de uma revista; seu sorriso simpático e solícito, como sempre, ainda que um pouco desconfiado. Vou até a estante e pego alguns poucos exemplares que ainda possuo. Talvez com esse suporte. Não. O estranhamento só aumenta. Há reconhecimento, claro, mas seria um truque barato tirar dele alguma intriga proustiana. A tentação da narrativa de formação também é grande, mas seria abusar da confiança do leitor. $\mathrm{O}$ que esse leitor espera? O que eu espero?

Talvez o que eu esperava. Ler o editorial que escrevi em 2001, reescrevendo-o nestas linhas, neste presente. Essa a intriga proposta, esse o truque para escapar da embaraçosa falta de memória e revisitar aquela experiência em torno da Vernáculo, tirando dela algum sentido. 
O texto fala de uma inquietação que, eu, então um estudante de História, sentia em relação ao papel da Universidade. O título, República dos Jornalistas, referia-se ao crescente número de publicações sobre história, escritas por jornalistas, que começava a aparecer no mercado editorial. A minha inquietação, pelo que posso desprender do texto e da minha suspeita memória, estava na incapacidade que a Universidade tinha de fazer visível, comunicável, a sua produção. E me perguntava, a partir desse diagnóstico, de que modo as ciências humanas, em particular, poderiam ocupar um lugar relevante no debate público. Como poderíamos, e aqui me permito o uso dessa primeira pessoa plural indefinida, transcender as fronteiras estreitas dos corredores departamentais e contribuir, efetivamente, para o enriquecimento de um debate crítico? O empreendimento de publicar uma revista acadêmica voltada para os estudantes de graduação era, sem dúvida, uma maneira de tentar achar uma resposta ou, ao menos, a possibilidade de articular a questão.

O número de publicações históricas produzidas por jornalistas, desde então, aumentou consideravelmente. O problema do monopólio dos meios de comunicação, que regulam e restringem o acesso dos indivíduos autorizados à tão propalada "liberdade de imprensa", continua um dos grandes desafios a serem enfrentados pela sociedade. No entanto, também cresceu, de maneira estrondosa, o número de publicações ligadas à universidade. No que diz respeito à História, particularmente, nunca houve tanta demanda pelas habilidades profissionais do historiador. As fronteiras parecem menos porosas; em parte pela vitalidade do campo historiográfico, 
sem dúvida, mas em grande parte, também, pela transformação da natureza dessa demanda pelo passado.

Algo que eu, então um estudante de História, não conseguia perceber, mas que agora, doze anos depois, posso identificar pelas frestas daquele texto, era uma mudança de relação que estava ocorrendo, e ainda está, entre a produção universitária de História e as outras esferas da sociedade. Eu concebia minha inserção na Revista Vernáculo, desde o início, como uma busca por expressão. Não vivíamos ainda, como estudantes de graduação, os efeitos da onda produtivista e dos índices acadêmicos. A motivação para criar uma revista, a ânsia por publicar, tinha sua origem em uma necessidade de expandir os meios através dos quais todos aqueles problemas teóricos e instrumentos analíticos que então incorporávamos pudessem ser comunicados, usados, testados, criticados. Quando eu imaginava e defendia, naquele texto, a necessidade de os historiadores ocuparem um maior espaço público, era pensando justamente na potencialidade de inteligibilidade e de crítica oferecido pelo discurso histórico e pelas ciências humanas como um todo.

$\mathrm{O}$ que eu não percebia, como disse, era a mudança da natureza da demanda que então se criava, a qual não buscava esses conceitos e problemas teóricos que tanto nos encantavam pela possibilidade de constituir um sentido crítico. O que surgia era, acima de tudo, uma demanda por memória. Quando da produção daqueles primeiros números da revista, eram ainda relativamente escassos os meios de divulgação não especializados da área de história, se comparados aos que temos hoje. A variedade de revistas 
em bancas, programas televisivos, coleções editoriais, sites, museus; enfim, uma longa lista de meios que se expandiram e se reproduziram para atender um novo desejo pelo passado. E não por acaso foram os jornalistas, atentos às demandas do mercado, os primeiros a investir nesse novo filão. Como um desses jornalistas pioneiros bem expressou: "É óbvio que as pessoas querem uma história do Brasil com mais sangue, com mais vida, com personagem de carne e osso, com mais ação e aventura, e com um texto jornalístico, não acadêmico". Não é possível, hoje, ignorar esse diagnóstico. Ao ignorá-lo, eu ignorava o estreitamento das possibilidades de inserção e de difusão de um discurso histórico que, sem deixar de se preocupar com a "vida", tinha por princípio decompô-la e submetê-la ao rigor de uma articulação conceitual. A aventura da compreensão cedia lugar à aventura de uma nova forma de presença do passado. Um passado de consumo, disponível, descartável.

A citação que fazia então de Valéry, expressando o desejo de conciliar o pensamento e o viver "sob os rostos e as imagens do conhecer", acabaram revelando-se parcialmente frustradas. Não saberia dizer, ou mensurar, o quanto essa nova demanda pelo passado/memória não acabou, ao contrário do que aquele estudante esperava, afetando a própria produção historiográfica acadêmica e sua inserção pública. $\mathrm{O}$ quanto, em meio a uma burocratização, muitas vezes confundida com profissionalização, o trabalho do historiador não acabou sendo vampirizado por essa nova demanda. Algo a ser pesquisado, refletido, ponderado. Mas não aqui. 
Reescrevendo esse editorial, como procedimento narrativo para lidar com minha experiência na Revista Vernáculo, endossaria ainda a voz daquele estudante, deslocando a ênfase da questão: da necessidade de romper os muros da universidade para a necessidade de uma reflexão sobre os modos que justificariam esse movimento, que já não parecem tão evidentes. Isso passaria por uma problematização, acima de tudo, da definição epistemológica que queremos dar para a disciplina histórica, afetando desde a estrutura que ainda rege a grade curricular dos cursos, até o perfil que esse historiador pode assumir enquanto sujeito de conhecimento e figura pública autorizada por instituições sociais, como a Universidade.

A existência e a persistência de lugares de reflexão com a Revista Vernáculo, que se alimenta das novas expectativas de estudantes também ansiosos por expressão, é uma condição fundamental - talvez menos para dar uma resposta a velhas inquietações do que para a elaboração de novas questões. Vida longa à Vernáculo! 